Article

\title{
Entrepreneurial Intentions of Business and Economics Students in Germany and Cyprus: A Cross-Cultural Comparison
}

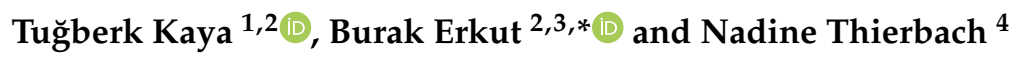 \\ 1 Department of Management Information Systems, School of Applied Sciences, Cyprus International \\ University, Nicosia, Northern Cyprus via Mersin 10, Turkey; tkaya@ciu.edu.tr \\ 2 Institute for Research in Economic and Fiscal Issues (IREF), 75017 Paris, France \\ 3 Department of Economics, Faculty of Business and Economics, Technische Universität Dresden, \\ 01062 Dresden, Germany \\ 4 Independent scholar, 01062 Dresden, Germany; thierbach.nadine@web.de \\ * Correspondence: burak.erkut@tu-dresden.de; Tel.: +49-351-463-34797
}

Received: 7 February 2019; Accepted: 28 February 2019; Published: 8 March 2019

\begin{abstract}
The World Economic Forum in Davos suggested that promoting entrepreneurship could be a solution to the problem of youth employment, which is a serious issue with 75 million young people out of work around the world. The entrepreneurial decisions of young people are especially important in regions where economic opportunities are restricted and people choose to move from that region. Two of such regions are East Germany and Northern Cyprus. In this article, the authors are interested in analyzing entrepreneurial tendencies of business and economics students from Northern Cyprus and East Germany in order to provide context-specific knowledge. For this purpose, a survey was conducted at the Technische Universität Dresden and the Near East University with $n=293$ participants in 2016. The results were analyzed by using a logistic regression analysis. The study includes with policy implications on the transformation towards entrepreneurial universities to meet the different needs of small and poor cities.
\end{abstract}

Keywords: entrepreneurship; entrepreneurial tendencies; student entrepreneurship; youth unemployment

\section{Introduction}

Germans believe that the German education system does not teach them the necessary skills for becoming entrepreneurially active. This was the result of Amway's Global Entrepreneurship Report in 2018 [1]. According to this research, only 35\% of Germans think that their education system provides them the entrepreneurial skills needed, which is below the EU average of $44 \%$. The regional inequalities and different needs of different regions for entrepreneurial activities seem to be not yet fully addressed by academia and practitioners.

It has been empirically observed that the problem of regional inequality is that of a core-periphery issue triggered by agglomeration economies, where East Germany seems to have a plethora of small and poor cities that make its overall economic performance worse than West Germany [2]. Understanding entrepreneurial tendencies of business and economics students in East Germany is important. As suggested by [2], there are still small and poor cities in Germany (mainly in the former East), which is the main explanation of why there is a divergence between the regions of Germany; a way out of this economic weaknesses can be entrepreneurship. Therefore, entrepreneurship support conditions for investing in these regions need to be supported by data analysis with respect to the future, since the case of the former East Germany is a special case for German entrepreneurship. 
Observing the structural properties of this special case and associating these with other cases of similar structures can broaden the perspective of the research, which the authors summarize as structural similarities going back to [3,4]. The concept of structural similarities in economic processes $([3,4])$ offers a method of comparison in economic processes as a midway between structural equality and structural inequality. According to this approach, two economic processes are structurally similar, if their properties constituting the definition of "structure" are similar. Therefore, structural similarities can give an interpretation for the regulations and governing laws in economic processes [4]. Recent empirical findings by [5] suggest that university graduates either stay in their university regions, return back to their home regions or look at employment opportunities for regions with structural similarities to their home regions. This mental comparison of structural similarities can be useful also with respect to going beyond the specific entrepreneurial and economic characteristics of a single region to a more general approach enabling policy contributions for multiple regions with structurally similar characteristics.

Regions that are structurally similar to the former East Germany in terms of their catch-up characters and content of small and poor cities can be further target groups for deriving future policy implications to promote entrepreneurship as a way out of economic weaknesses, where the scope of the analysis and the policy implications can go beyond the special case of East German entrepreneurship. One such region is Northern Cyprus. The Cyprus dispute, which has its roots in the ethnic conflict between the two main communities of the island-Turkish Cypriots and Greek Cypriots-led to the division of the island, with Turkish Cypriots living in the northern part and Greek Cypriots living in the southern part. The economic differences between the two parts of the island are massive, with Greek Cypriots being the richer of the two communities due to the isolation of the Turkish Cypriot community from direct political and economic relations with the rest of the world [6], which started to change in a limited extent after the EU accession of the Republic of Cyprus. In other words, the structural similarity between East Germany and Northern Cyprus is associated with both regions having relatively small and poor cities in comparison. Understanding entrepreneurial tendencies of business and economics students in Northern Cyprus is important due to the fact that the Turkish Cypriot community is on the way to the European economic integration, which was made possible after the EU accession of the Republic of Cyprus and the Green Line Regulation of the European Union in May 2004 [6], through which trade relations between the North and the South as well as between the North and the rest of the EU was enabled and the Turkish Cypriot community got monetary support from the EU to enhance the European integration process both in economic and social terms. Understanding the potentials of entrepreneurial dynamics in this region can be helpful for the further economic integration into the common market.

Therefore, the authors set the aim of the paper to be understanding entrepreneurial tendencies of business and economics students in structurally similar regions in order to provide context-specific knowledge, as highly recommended by [7]. The authors will proceed in the rest of the paper as follows: In the second chapter, an overview of the relevant literature will be given. Since the concept of structural similarities is associated with observing economies as evolving processes over time, this section primarily focuses on entrepreneurship as a dynamic concept of discovery in the sense of [8]. This chapter builds the basis of the survey used to measure entrepreneurial tendencies. The third chapter involves descriptive statistics and a logistic regression analysis to outline factors strengthening the odds of being entrepreneurially active in the future. In the fourth chapter, the authors discuss the results whereas in the fifth chapter the authors derive conclusions and policy implications and list the limitations of the current study with an overview of potential future research areas. 


\section{Literature Review}

\subsection{Entering the Economic Mainstream}

The point of departure is the need for entrepreneurship in an economic environment, where not all opportunities have been discovered yet. Entrepreneurship is seen as the driving force of the market process, where the contributions of entrepreneurial firms are associated with the way they change the market structure through competition and their role as a mechanism for people to enter the economic mainstream [9].

Entering the economic mainstream goes back to the entrepreneurial discovery in the sense of [8]. Discovery is described as being on the midway between deliberately produced information and sheer windfall gain [8]. The dual core of entrepreneurial discovery is based on: (1) the entrepreneurially driven market process and (2) the competition as a discovery procedure based on the dispersed knowledge in the society, where each economic actor possesses unique knowledge relevant for the market interaction [8]. As the entrepreneurs constantly search for new opportunities or new ways of doing things, they also trigger innovation [10].

In fact, self-employment in terms of small businesses has gained importance in modern economies, since it has been observed as an effective way of reducing unemployment. There are around 22 million small- and medium-size enterprises (SMEs) in Europe [11]. Around 3.7 million SMEs are located in Germany [12]. The estimated economical contribution of SMEs is around 35\% of the total revenues of firms, and corresponding to $99.5 \%$ of all private firms within Germany [12]. There are around 12 thousand SMEs located in the northern part of Cyprus, corresponding to $98.9 \%$ of all private firms in Northern Cyprus [13].

In the entrepreneurship literature, two effects are mentioned [14] that emphasize the relationship between entrepreneurial activity and employment level in an economy: the refugee effect corresponds to the case that increased unemployment leads to an increase in the establishment of start-ups, because of the reduced opportunity cost of the latter. The entrepreneurial effect, on the other hand, corresponds to the case that start-ups hire unemployed people and reduce unemployment, since unemployed people do not have entrepreneurial skills. Although these two effects contradict each other, empirical evidence supports both effects in a simultaneous way over a long period [14].

In both cases, economically disadvantaged regions of a country are especially relevant. With respect to the refugee effect, it can be easy to conclude that the opportunity costs of start-ups are especially low in economically disadvantaged regions. With respect to the entrepreneurial effect, start-ups again have a bigger pool of human capital to select for employment. In a European perspective, [15] observe how these economically disadvantaged regions are supported with the target of an increase in GDP-per-capita growth. Although the relevant transfers (in the case of EU) increase the GDP-per-capita growth significantly, the authors do not find any significant effect of transfers to employment, pointing out the fact that such transfers are mainly investment-oriented, and creation of jobs can take more than the duration of the program of transfers [15]. In two follow-up works, the authors propose a reallocation of the provided funds to catalyze the convergence process [16] and find out that the quality of government and the human capital endowment of a region is a decisive factor for the effectiveness of investments via transfers [17]. These two factors are also decisive for understanding the relation between economic freedom of a country, and the entrepreneurial activities at nascent stage, as put forward by [18]. From the perspective of universities and their scope of regional action, human capital is the decisive factor, since it is accepted as a factor influencing the knowledge capacity of a region $[19,20]$.

Identifying profit opportunities that have not previously been discovered is an intentional process [21] based on the cognitive model of the potential entrepreneur who discovers this opportunity. Since what a potential entrepreneur will discover, or how he or she will discover that particular idea, cannot be planned in advance [8], the focus and the efforts of the research and evidence based entrepreneurship policy is on the pre-step of this discovery process, this process of knowledge 
generation on the marketplace. This pre-step has long been neglected by the evolutionary economics, a discipline observing changes coming from within the system instead of external shocks. Scholars like [22] wrote that "Turning to reality, it can be said that an evolutionary model starts when one or more of the agents use initiative and imagination to generate an option - say, to produce and introduce into the market a new consumer item or new production technique" (p. 30), without explaining how and why a certain initiative is shown, a certain type of item is produced or how the imagination of a person works in a certain, meaningful way without the intervention of a central planner that something novel comes out. These all pointed out to the need for further exploration of understanding the pre-step of the knowledge generation on the marketplace, since this is central to any opportunity creation attempt as well as the attempts to develop the discovered opportunities [23].

An answer to this question was given by [24] by introducing the nano dimension to the evolutionary economic framework. This dimension introduces to the evolutionary economic framework an explanation of how tacit, individual knowledge is generated in the human mind and serves as a pre-step of the knowledge generation on the marketplace. By looking at the way the human mind performs categorization of the outside world based on the previous experiences that are restored in a hierarchical way of networks, any new experience with the outside world initiates a pattern recognition in the human mind that associates the new experience with similar experiences that gave the mind a similar sensation in the past $[25,26]$. Through this pattern recognition, new, individual knowledge is generated, which serves as the starting point of the knowledge generation on the marketplace. The pre-step of the knowledge generation on the marketplace, perceptions, correspond to the nano dimension of the evolutionary economic framework, serving as a fuzzy front end for the knowledge generation [24]. Therefore, not only is the relevant starting point for any evolutionary economic model the start of this pattern recognition in the human mind, but also entrepreneurship research is answering the question of where to focus in the same fashion as the nano dimension-only the potential of entrepreneurial activity can be predicted, not the type of novelties this potential will carry on to the economy.

This focus on the pre-step of knowledge generation on the marketplace, in other words, on the nano dimension of perceptions, is relevant for policy designs that can accelerate the transformation of tacit knowledge relevant for the market to explicit knowledge codified and made available to the market. Hence, it is important to examine the intentions of university freshmen to derive middle term policy implications for the transformation towards an entrepreneurial university, which "encompasses teaching, research and service for society" [27] (p. 10). An entrepreneurial university generally works with its industry partners for bringing together application and discovery [27] in form of "experiential learning opportunities" [28] (p. 240). Important for an entrepreneurial university is to be able to connect its students with the real world and both internships and leadership opportunities can be seen as different channels shaping the relation of the students with the real world [28].

The concept of an entrepreneurial university is especially important for innovation driven economies such as Germany, where science parks and business incubators are less effective in comparison to efficiency driven economies, and consultants as well as subcontractors are not easily accessible for start-ups [20]. This structural similarity of innovation driven economies challenges start-ups to find new and accessible ways for shaping new markets. In innovation driven economies, the focus is more on business sophistication and global strategies, where product differentiation plays an important role; therefore, a new or growing firm has to offer a completely new product for exploiting market gaps [20], or a service (e.g., in the form of a solution offered to a social problem) [29].

Northern Cyprus as an efficiency driven economy [30] still lacks science parks and business incubators, although these can be more effective for the entrepreneurial activity in comparison to innovation driven and factor driven economies [20]. Hence, the need for business incubation centers points to a possible transformation towards entrepreneurial universities in order to support the new generation of potential entrepreneurs with the capabilities they can gain to become entrepreneurs. The structural similarity of efficiency driven economies is the fact that entrepreneurship is a desirable 
career choice due to the fact that business sophistication is not at the highest stand as it is in the innovation driven economies [20]. Hence, the plethora of good opportunities to create start-ups can be accompanied by centers focusing on the capability development for potential entrepreneurs.

Even though the two economies differ from each other in certain terms regarding their competitiveness, the common need in both cases is to create suitable conditions for attracting the young population of the small and poor cities to enter the economic mainstream by entrepreneurial activity. Since this occurs upon planned decisions of individuals, it is important to provide potential entrepreneurs with working tools to develop their own capabilities for entering the economic mainstream. Even though the key issue behind any entrepreneurial decision process is to turn tacit knowledge into a competitive advantage on the marketplace [31], business conceptions are necessary for transforming the discovery into a viable business model based on a common cognitive framework for the members of the organization [32,33]. Nevertheless, this issue has been neglected by the Neo-Schumpeterian tradition of evolutionary economics over the years [32]. Entering economic mainstream does not occur merely with technological knowledge, or any discovery on its own, contrary to the belief of Neo-Schumpeterians. Capabilities of individuals to generate business conceptions, and suitable ways for them to develop these capabilities, can be accelerated within an entrepreneurial university environment. As put forward by [19], capabilities may be associated with the individuals' capacities for information technologies, organizations and knowledge. How these capabilities can be accelerated by the universities can only be understood, once factors influencing entrepreneurial intentions of their students can be identified.

\subsection{Factors Influencing Entrepreneurial Intentions}

An open-loop evolving economic system in historical time is characterized with the emergence of novelties that are not foreseeable [34]. The economic system is therefore not planned, not plannable and comes into existence as a result of the interaction of heterogeneous actors whose actions are partly rational and partly due to the influences of social, emotional and cultural contexts [34]. Developments in technology and the high penetration of information and communication technologies increase connected economies (globalization), where this connection will also increase the speed of innovation due to fierce competition. The firms that are not able to innovate either become bankrupt or lose their market dominance (e.g., Nokia).

The fact that the observed economic system is open loop evolving does not mean that we cannot make predictions about the link between entrepreneurial intentions and future entrepreneurial activity. Two types of change in an evolving system are defined as genotypic (unpredictable) and phenotypic (predictable) changes, where [34] classified the actions of economic actors as predictable. Unpredictable changes occur when the "genotype" of the economic structure changes with the introduction of novelties [35]. In the context of this research, the entrepreneurial behavior of students can be predicted, but not the types of novelties they may introduce to the economy.

\subsubsection{Demographic Variables}

Some demographic variables can be helpful to understand the heterogeneity among students and how the corresponding variation can be explained for entrepreneurial intentions. For this purpose, the following demographic variables are considered.

The authors of [36] find that men are more eager to become entrepreneurially active. Using quantitative genetic techniques, [37] empirically observed that genetic factors may influence entrepreneurial intentions; however, they do not determine the decision to be entrepreneurially active. In an experimental setup, the market entry decisions of female entrepreneurs were explained by a general dislike of strategic competition among females [38]. Therefore, the authors hypothesize:

H1. Gender will be associated with the intention in becoming entrepreneurially active. 
Having an entrepreneur in their own family can be a further variable influencing entrepreneurial tendencies. The authors argue that this can be relevant due to the environment students grow up in, as those who had experienced and learned the entrepreneurship concept in their formative years could be affected accordingly. An entrepreneurially active family member may influence students' perception of new business opportunities with establishing a company and being entrepreneurially active $[37,39,40]$ Given the empirical evidence, the hypothesis is:

H2. Entrepreneurial family will be associated with the intention in becoming entrepreneurially active.

The effect of a previous internship can be positive [28,41] or negative [42] for entrepreneurial tendencies. Students may be affected by corporate life during their internship, and their perception can move towards corporate, clear and low-risk careers. Although corporate life seems more secure when compared with entrepreneurship, where there are many unknowns $[43,44]$ argued that it has similar risks as working for a bank. Given the empirical evidence, the authors hypothesize:

H3. A previous internship experience will be associated with the intention in becoming entrepreneurially active.

Student engagement in university clubs can accelerate entrepreneurial learning through learning-by-doing activities [45]. The authors interpret the presence of university clubs as a leadership opportunity for students, which can make a connection with the real world [28]. Active student clubs at the Faculty of Business and Economics of the TU Dresden are mainly targeting business consulting and understanding stock markets. Active student clubs at the Faculty of Economics and Administrative Sciences of Near East University are a mixture of cultural societies such as football and cinema clubs and societies dealing with economics and politics, which still can have an indirect effect on entrepreneurial decisions. Therefore:

H4. Student engagement will be associated with the intention in becoming entrepreneurially active.

\subsubsection{Entrepreneurship Support Culture}

The personal characteristics of a person along with his or her interactions with society can be decisive in the entrepreneurial activity. Social relations can support both knowledge transfer and the relevant resources for the entrepreneurial activity [46]. Hence, the existence of an entrepreneurial culture that rewards entrepreneurs and supports social engagement can be relevant for capturing this phenomenon. This aspect is clearly associated with the recognition of opportunities that can be turned into innovations - as one of the main resources of the emergence of innovations. Hence, the authors propose:

H5. Entrepreneurship support culture will be associated with the intention in becoming entrepreneurially active.

The authors measure this phenomenon with the following variables in the survey, which are presented in Table 1 below.

Table 1. Measuring entrepreneurship support culture.

\begin{tabular}{ccc}
\hline Variable & Question in Survey & Based on \\
\hline "In my country, there are more & \\
Opportunity Recognition & $\begin{array}{c}\text { good opportunities for creating a } \\
\text { new firm than people who are able } \\
\text { to take advantage of them." } \\
\text { "Entrepreneurs will be rewarded } \\
\text { bewarding Entrepreneurs }\end{array}$ & $\begin{array}{c}\text { Global Entrepreneurship } \\
\text { Monitor }\end{array}$ \\
"My country." & \\
Support Culture & entrepreneurial culture." & \\
Social Engagement & "Social engagement will be & \\
& rewarded in my culture." & \\
\hline
\end{tabular}




\subsubsection{Cultural Values}

In addition to the entrepreneurship support culture, deeper cultural values regarding the social norms can be relevant factors for the entrepreneurial intentions. In line with [46,47], the authors propose that social norms based on self-sufficiency and self-responsibility can influence entrepreneurial tendencies. The authors propose that:

H6. Cultural values regarding self-management will be associated with entrepreneurial intentions.

The authors measure this phenomenon with the following variables in the survey, which are presented in Table 2 below.

Table 2. Measuring cultural values.

\begin{tabular}{ccc}
\hline Variable & Question in Survey & Based on \\
\hline Self-Sufficiency & "My culture emphasizes \\
self-sufficiency, autonomy and \\
personal initiative." \\
"My culture emphasizes the \\
Self-Responsibility & $\begin{array}{c}\text { responsibility that the individual has } \\
\text { in managing his/her own life." }\end{array}$ & $\begin{array}{c}\text { Monitor } \\
\text { in }\end{array}$ \\
\hline
\end{tabular}

\subsubsection{Lead Users}

Being a lead user [48] is relevant both in a technological and a social context, since this is highly related to recognizing opportunities that the market does not yet offer, and it is very often that lead users also become lead user entrepreneurs [49]. A lead user is the user of a product who faces needs before the marketplace encounters them with existing products. For identifying (technological) lead users, the authors specify by asking students whether they follow new trends in technological products and whether they are satisfied with them in order to understand whether some students are actually ahead of the market. These two questions go back to the concept suggested by [48] and later on operationalized by [50]. Therefore, the authors hypothesize the following:

H7. Technological lead users will be associated with the intention in being entrepreneurially active.

In addition to the original meaning, the lead user is interpreted by the authors in the sense of a social lead user, whose social vision is beyond the existing market for providing solutions to social problems [49]. The latter observation goes back to [29], who identified social entrepreneurship as a result of discovering opportunities to solve a social problem. For identifying social lead users, awareness of social problems in the surroundings and social innovation as a solution mechanism instead of the expectancy for state intervention [49].

H8. Social lead users will be associated with the intention in being entrepreneurially active.

The authors measure these two issues with the following variables in the survey, which are presented in Table 3 below.

Table 3. Measuring lead users.

\begin{tabular}{ccc}
\hline Variable & Question in Survey & Based on \\
\hline Social Alertness & "I am aware of the social problems in my & \\
surroundings." & [29], [49] \\
Perseverance & "With a social innovation, I can cope against social & injustice. \\
Social Innovativeness & "I am aware that I can transform the social & \\
Technological Alertness & "Current technology is not sufficient for my needs." & [48], [50] \\
Technological Trend-Following & "I follow new trends in technology." & [51] \\
\hline
\end{tabular}




\subsubsection{Need for Autonomy}

In the entrepreneurial context, the need of an individual for autonomy in his/her life can be expressed in terms of self-employment [37]. The choice of the subject of studies with the aim of self-employment, and therefore, being entrepreneurially active, can be considered as a deliberate and intentional choice of that individual aiming for more autonomy. This claim was empirically shown by [52] in which the authors conducted a survey with more than 3000 graduates of Babson College, who took entrepreneurship classes. The authors found out that taking three classes on entrepreneurship increases the odds of becoming an entrepreneur, whereas taking only one class does not have this effect; and the fact that being a full time student also increases the odds of becoming an entrepreneur.

Self-efficacy is expressed in terms of economic management of one's own expenses. Here, the authors operationalize the ability to manage expenses with an item suggested by [53]. The challenge is expressed in terms of learning entrepreneurship on one's own. In the survey, the authors operationalized this concept based on [54]. Therefore, the authors propose that the individual's need for autonomy in terms of the choice and the perception of studies towards the ultimate entrepreneurial activity, the ability and capability to manage their own expenses and learn entrepreneurial activity can be expressed in terms of autonomy to hypothesize:

H9. The need for autonomy will be associated with the intention in being entrepreneurially active.

The authors measure autonomy with the following variables in the survey, which are presented in Table 4 below.

Table 4. Measuring autonomy.

\begin{tabular}{lll}
\hline Variable & Question in Survey & Based on \\
\hline Intentional Choice of Studies & "In my country, there are more good opportunities for creating a & \\
Perception of the Choice of Studies & new firm than people who are able to take advantage of them." & [52] \\
Self-Efficacy & "Mytrepreneurs will be rewarded by my country." & \\
Challenge & "Social engagement will be rewarded in my culture." & {$[53]$} \\
\hline
\end{tabular}

\subsubsection{Financial Security under Uncertainty}

Financial security under uncertainty captures two issues in the framework of the authors. The tendency towards financial security and the knowledge on venture capital opportunities in the market. For the availability of venture capital opportunities, the question is based on Global Entrepreneurship Monitor. For financial security, the question is based on the analysis of [55] of the elimination of bankruptcy, which would lead to a reduction in entrepreneurship. The fact that risk-taking behavior is a determinant of entrepreneurial intentions does not eliminate the possibility of a risk-averse person's choice of being entrepreneur at a later stage. This possibility was evaluated by [43] by concluding that entrepreneurship is a social activity contingent on time and place. This is a type of change that cannot be predicted in advance by any type of forecast. This possibility highlights that the observed economies are evolving systems in an open loop, i.e., not a pre-determined environment [56]. Based on these thoughts, the authors hypothesize the following:

H10. Financial security under uncertainty will influence entrepreneurial intentions.

The issue will be captured with the following variables in the survey, which are presented in Table 5 below: 
Table 5. Measuring financial security under uncertainty.

\begin{tabular}{|c|c|c|}
\hline Variable & Question in Survey & Based on \\
\hline Venture Capital & $\begin{array}{l}\text { "In my country, there is sufficient venture capitalist } \\
\text { funding available for new and growing firms." }\end{array}$ & $\begin{array}{l}\text { Global Entrepreneurship } \\
\text { Monitor }\end{array}$ \\
\hline Financial Security & $\begin{array}{l}\text { "If there is a possibility of bankruptcy, I would not } \\
\text { prefer to be an entrepreneur." }\end{array}$ & [55] \\
\hline
\end{tabular}

\section{Results}

The surveys were conducted in 2016 during a microeconomics lecture, which is an obligatory course for undergraduate students enrolled in the Faculty of Business and Economics of TU Dresden, a public university in Dresden, Germany; and during an introductory business lecture, which is an obligatory course for undergraduate students enrolled in the Faculty of Economics and Administrative Sciences of Near East University, a private university in Nicosia, Northern Cyprus. Both universities had around 200 freshman students during the period of observation. Near East University had around 1400 students enrolled in undergraduate and postgraduate programs of the Faculty of Economics and Administrative Sciences [57], whereas TU Dresden's Faculty of Business and Economics had around 2700 [58]. For the survey in Dresden, 200 questionnaires were distributed and 190 were collected, of which, 151 were returned with completed answers. In Nicosia, also 200 questionnaires were distributed and 166 were collected, of which 142 were returned with completed answers. Since, in both cases, there is no obligation of taking the courses during the freshman year, both freshman and senior students took place in the survey and the number of questionnaires distributed corresponded to the approximate number of students attending the corresponding lectures. Both courses can be considered as introductory courses into the corresponding topics. Demographich information about participants can be seen in Table 6.

Table 6. Participants.

\begin{tabular}{lllll}
\hline Group Profiles & \multicolumn{2}{l}{ TU Dresden $(\boldsymbol{n}=\mathbf{1 5 1})$} & \multicolumn{2}{l}{ Near East University $(\boldsymbol{n = 1 4 2})$} \\
\hline $\begin{array}{l}\text { Characteristic } \\
\text { Education }\end{array}$ & Frequency & Percentage & Frequency & Percentage \\
$\begin{array}{l}\text { Freshman } \\
\text { Senior }\end{array}$ & 133 & 88.1 & 103 & 72.5 \\
Gender & 18 & 11.9 & 39 & 27.5 \\
Male & & & & \\
Female & 71 & 47 & 93 & 65.5 \\
Entrepreneurial Intentions & 80 & 53 & 49 & 34.5 \\
With Intention & 131 & 86.8 & 123 & 86.6 \\
Without Intention & 20 & 13.2 & 19 & 13.4 \\
\hline
\end{tabular}

The survey questions described in the previous section were based on a five-point Likert scale, varying from strongly disagree to strongly agree. Overall, Cronbach's alpha as a measure of internal consistency is 0.640. This shows that the questionnaire has a good level of internal consistency [59]. The authors utilized an empirical strategy based on a principal component analysis and a logistic regression analysis aiming to highlight the relationship between entrepreneurial factors, demographic variables and entrepreneurial intentions. Whereas the principal component analysis with rotated orthogonal factors ensures to get rid of the problem of multicollinearity, logistic regression analysis provides a method to investigate the rotated factors influencing entrepreneurial intentions [60].

$\chi 2$ tests of independence are conducted to ensure that no systematic differences affected the results in terms of the demographic variables. Therefore, for the two groups of students in Dresden and Nicosia, the tests are based on the distinction between freshman students and senior students. These demographic factors are gender, having at least one family member who is entrepreneurially active, having done an internship and being active in a student club. For these demographic factors, no 
statistically significant difference is found between freshman and senior students, where the authors assumed a significance level of 0.05 . Furthermore, in the case of entrepreneurial intentions between freshman and senior students, no statistically significant difference is found. This leads to conclude that both groups of students show similar tendencies for entrepreneurial activity.

For the survey results, a principal component analysis with varimax rotation is conducted. The Kaiser-Meyer-Olkin Test for sampling adequacy delivered a mediocre result of 0.619 ; since this value is above the 0.5 threshold suggested by [61] as the threshold for acceptable values, the sampling adequacy was met. Bartlett's test for sphericity testing the original correlation matrix for being an identity matrix was highly significant $(0.000)$ indicating that the correlation matrix is not an identity matrix and that the factor analysis is an appropriate method for analyzing the data. The principal component analysis with varimax rotation delivered seven factors with Eigenvalues greater than 1 (selection criterion) and an overall explained variance of $62.981 \%$. The rotated component matrix is visualized below in Table 7 .

Table 7. Rotated Component Matrix.

\begin{tabular}{|c|c|c|c|c|c|c|c|}
\hline Variable & $\mathrm{C} 1$ & $\mathrm{C} 2$ & $\mathrm{C} 3$ & $\mathrm{C} 4$ & C5 & C6 & $\mathrm{C} 7$ \\
\hline Opportunity Recognition & 0.718 & & & & & & \\
\hline Rewarding Entrepreneurs & 0.700 & & & & & & \\
\hline Support Culture & 0.479 & & & & & & \\
\hline Social Engagement & 0.479 & & & & & & \\
\hline Self Sufficiency & & 0.801 & & & & & \\
\hline Self-Responsibility & & 0.751 & & & & & \\
\hline Social Alertness & & & 0.695 & & & & \\
\hline Perseverance & & & 0.695 & & & & \\
\hline Social Innovativeness & & & 0.680 & & & & \\
\hline Technological Alertness & & & & 0.889 & & & \\
\hline Technological & & & & & & & \\
\hline Trend-Following & & & & 0.844 & & & \\
\hline $\begin{array}{l}\text { Intentional Choice of } \\
\text { Studies }\end{array}$ & & & & & 0.766 & & \\
\hline $\begin{array}{l}\text { Perception of the Choice } \\
\text { of Studies }\end{array}$ & & & & & 0.743 & & \\
\hline Financial Security & & & & & & 0.751 & \\
\hline Venture Capital & & & & & & 0.560 & \\
\hline Self-Efficacy & & & & & & & 0.822 \\
\hline Challenge & & & & & & & 0.599 \\
\hline
\end{tabular}

These results are in line with the theoretical considerations and literature review that were presented in the previous chapter of the article. Hence, the authors name $\mathrm{C} 1$ as "Entrepreneurship Support Culture", C2 as "Cultural Values of Self-Management", C3 as "Social Lead User", C4 as "Technological Lead User", C5 as "Need for Autonomy in Studies", C6 as "Financial Security under Uncertainty" and C7 as "Need for Autonomy in Careers".

A logistic regression analysis is performed for the total sample of 293 students in order to understand and analyze the effects of the seven orthogonal components as well as demographic variables on entrepreneurial intentions. All variables in a block were entered in a single step to the logistic regression model. The model included the demographic variables of family background in entrepreneurship, gender, student engagement in university clubs and previous internship experience as well as a binary indicating whether the survey was conducted in Cyprus or in Germany. The analysis is performed with the dependent variable "I intend to establish my own company" to analyze the contribution of individual independent variables to the entrepreneurial intentions, where the dependent variable is a binary with the answer categories "Yes" and "No". The results of the logistic regression analysis are presented in Table 8. 
Table 8. Logistic regression analysis.

\begin{tabular}{lllll}
\hline Variable & $\begin{array}{l}\text { Regression } \\
\text { Coefficient B }\end{array}$ & Standard Error & Wald & Exp(B) \\
\hline Sample & 1.632 & 0.398 & 16.838 & $5.112^{* * *}$ \\
Gender & 0.912 & 0.380 & 5.775 & $2.490^{* *}$ \\
Family & 0.780 & 0.431 & 3.270 & $2.182^{*}$ \\
Student Club & -0.263 & 0.395 & 0.443 & $0.769^{* * *}$ \\
Internship & 1.755 & 0.439 & 15.952 & $5.783^{* * *}$ \\
$\begin{array}{l}\text { Entrepreneurship Support } \\
\text { Culture (C1) }\end{array}$ & 0.829 & 0.213 & 15.128 & $2.290^{* * *}$ \\
Cultural Values of & 0.775 & & & \\
Self-Management (C2) & & 0.203 & 14.629 & $2.170^{* * *}$ \\
Social Lead User (C3) & 0.464 & & & \\
Technological Lead User (C4) & 0.951 & 0.208 & 4.969 & $1.591^{* *}$ \\
$\begin{array}{l}\text { Need for Autonomy in Studies } \\
\text { (C5) }\end{array}$ & 0.709 & 0.227 & 8.607 & $2.588^{* * *}$ \\
$\begin{array}{l}\text { Financial Security under } \\
\text { Uncertainty (C6) }\end{array}$ & -0.530 & 0.239 & & $2.033^{* * *}$ \\
$\begin{array}{l}\text { Need for Autonomy in Careers } \\
\text { (C7) }\end{array}$ & 0.208 & 0.215 & 6.093 & $0.588^{* *}$ \\
\hline
\end{tabular}

Number of observations: 293. Entrepreneurial intention was coded dichotomously; 1 = having no intention and $2=$ having intention to establish a business. Reference categories for the dichotomous variables were Sample: Nicosia, Gender: Female, Family: No entrepreneurial family, Student club: No student club engagement, Internship: No previous internship experience. ${ }^{* * *} p<0.01 ;{ }^{* *} p<0.05,{ }^{*} p<0.1$. Nagelkerke Pseudo-R2: 73.4\%. Hosmer-Lemeshow Test: Chi-Squared 12.994, df $=9, p=0.112$.

\section{Discussion}

In the following, the authors focus on the last column of Table 8-Exp(B)-which gives the odds ratios, and interprets the results by looking at the hypotheses listed previously. It was determined that male students are more likely to establish their own firms than female students, supporting H1. This contradicts the findings of [37] and is supported by the findings of $[36,38]$. Those with an entrepreneur in their family are more likely than those without an entrepreneur in their family to become entrepreneurs after finishing their studies, supporting $\mathrm{H} 2$. The findings are in line with those of [37], who found that self-employment can be heritable from the elder generations of the family, the so called heritability hypothesis. The findings are also in line with [39,40], who both find a significant relationship. Since having an entrepreneurially active family member and seeking a career in the same path can be interpreted as continuing a tradition, this contradicts the findings of the Amway Global Entrepreneurship Report [36], which states that entrepreneurship is not associated with tradition. Another entrepreneurial environment can be the engagement in (mainly business-related) university clubs. However, the analysis does not find any significant relationship differentiating those who are active in a student club and those who are not regarding their entrepreneurial tendencies, not supporting H4. The authors explain this finding with the lack of student clubs focusing on entrepreneurship-at the TU Dresden there is only one student club with a direct focus on entrepreneurship, at the NEU there is none. The effect of a previous internship experience was found to be positive, since those who had completed an internship previously are more likely to be entrepreneurs than those who did not do an internship, supporting H3. The authors argue that this is in line with the research of [28], who argues that internship experiences shape the perceptions of students in terms of their entrepreneurial tendencies.

The authors found out that both the entrepreneurship support culture (H5) and the cultural values regarding self-management (H6) increase the odds of future entrepreneurial activity, which are both in line with $[46,47]$. Results of the regression analysis supports H7, putting a clear difference between those who are ahead of the market for technological products and those who are not, supporting the original theory of [48] and its operationalization by [50]. In line with the importance of social entrepreneurship, as highlighted by authorities such as the World Economic Forum, the regression 
results indicated that those students who can be described as social lead users focusing on social problems and being aware of the possibility of solving these with social innovations are more likely to be entrepreneurs than those who cannot be described as social lead users, supporting H8. The authors argue that this is due to the fact that even though there are well-developed public sector institutions and Non-Governmental Organizations in both Germany and Northern Cyprus, there are still missing markets where social entrepreneurship could arise. This result also points out to the fact that no matter how well-developed public sector institutions are, they are unable to recognize the social problems the way individuals recognize them in a given region. In other words, locally available dispersed and subjective knowledge is something which any central authority is pre-determinedly unable to recognize, and build upon it so that it can be utilized for solving social problems. Also in the social context the authors find traces of the pretence of knowledge problem described by F. A. von Hayek in his Nobel Memorial Prize speech [62].

The need for financial security under uncertainty decreases the odds of entrepreneurial activity, since it was found out that those students who are more eager to guarantee their financial security by avoiding entrepreneurial activity in case of a bankruptcy, and rely to the availability of venture capital funding possibilities without any securities are less eager to become entrepreneurs, supporting H10. This is understandable as risk-taking and uncertainty are some of the common features of entrepreneurship. The need for autonomy in studies, in terms of an intentional choice of the studies as well as its perception towards the desired career goal of entrepreneurship, influences entrepreneurial intentions. Entrepreneurship should not be treated as homogenous as [63] stated. Therefore, different perceptions about the effect of education and entrepreneurship are understandable [64]. Furthermore, the shift "from teaching entrepreneurship to learning entrepreneurship" [65] (p. 193) is important. This shift requires the individual action by means of developing "know why" (attitudes and intentions) and "know how" (tools and guidelines) [65], which both build the basics of the pre-step of knowledge generation on the marketplace, the nano dimension of perceptions [24].

The findings supporting $\mathrm{H} 9$ contradict with the traditional entrepreneurship approach, where examples of well-known entrepreneurs such as Michael Dell (Dell Computers), Steve Jobs (Apple), Bill Gates (Microsoft), Evan Williams (Twitter co-founder), Mark Zuckerberg (Facebook), Larry Ellision (Oracle) and Jan Koum (WhatsApp) are all dropouts from university. These findings are in line with the findings of [66] who analyze the entrepreneurial activities of Danish college graduates and dropouts and do not find any significant difference between these two groups after controlling the endogeneity of already taking the decision of entrepreneurial activity before leaving the college. The authors did not identify potential entrepreneurs who believe that entrepreneurship skills can be learned by the individuals themselves, leading to an insignificant result for the need for autonomy in careers. The findings of this study indicate that entrepreneurial institutions can play a strategic role for higher education in both Germany and Northern Cyprus. World economic problems are expected to be solved via entrepreneurial solutions, which has been highlighted in most of the prestige economic events, such as the World Economic Forum. One of the key topics of that conference was how to create 75 million entrepreneurs in order to boost the economy, which will also help to reduce the current youth unemployment rate of 5.2\% [67]. A problem that Germany faces is its corporatist culture, where "strong trade unions and business associations, religion-based institutions, professional associations and chambers stick to their traditional roles", in order to "join forces with a strong state, which is still expected to solve the structural problems of the country" [68] (p. 111). This leaves no space for an entrepreneurially driven culture and, even Johanna Wanka, an East German professor of mathematics and a former Federal Minister of Education, admits that this is never going to change [69]. She compares German culture with the US-American culture, where the state is not as strong as it is in Germany, leaving an open space for individuals to establish companies, fail, get support, and eventually succeed in a non-linear way.

There is a decreasing trend of youth unemployment in Germany. With a rate of $6.8 \%$, it is significantly below the average for the euro area (16.8\%) [70]. A closer look at the former East and West 
German federal states shows that West German states have a lower average (4\%) than East German states (7.4\%) [71]. The authors of [72] notice the divergence in economic structures between the East and West by assuming that "increasing returns to scale in production leads to faster rates of the diffusion of technological progress or of a greater availability of skilled manpower, thereby making marginal productivity in the prospering centers higher than in the structurally weak regions" (p. 18). Regarding East Germany, [72] considers entrepreneurship to be an important factor triggering economic growth because of two reasons: Firstly, because of the aging population in East Germany, some firms will close down in the future; therefore, an entrepreneurial stock is needed. This forecast was in fact a self-fulfilling prophecy, since the IfM Bonn estimates that around 70,000 jobs are endangered because around 5300 managerial successors for SMEs are needed in Saxony [73]. In addition, entrepreneurship is also important for a transformation in the technological endowment of the region as well as for creative ideas.

In fact, these ideas that go back to 2009 are still valid and were promoted on a global scale by the World Economic Forum in Davos in 2016, where the possibility of creating 75 million entrepreneurs was discussed and set as a target to solve the issue of youth unemployment. According to the United Nations, there are around 75 million unemployed young people around the world, which is a serious problem [67]. Recent findings of entrepreneurship scholars such as [74,75] find out that youth has a different potential and especially entrepreneurial education is a relevant factor for providing this special group of people with the necessary skills to act.

Of course, entrepreneurship cannot be thought of a purely technological activity, in contrast to what [72] suggests. The evolution of the concept of lead users [48] shows that the focus has shifted from a pure technological approach to the interpretation of technology in a social context [76]. Entrepreneurship can also be relevant for discovering a profit opportunity by offering a solution to a socially relevant problem [29].

This latter point has been observed by the authors in their field research consisting of case studies from Northern Cyprus and East Germany [77]. The special case of Cyprus is both a challenging and an enabling factor for entrepreneurial activity. On the one hand, the two economies of Cyprus make it challenging for the entrepreneurs to cope with two different taxation bodies and two different currencies, just to name a few. On the other hand, new models of joint ventures are emerging across the divide, which are mainly seen in the framework of the economics of the internet [77]: One striking example is CyprusInno, a web platform bringing together entrepreneurs from both communities digitally and physically, also by offering them a consulting program where Turkish Cypriot entrepreneurs help Greek Cypriot entrepreneurs enter the market in Northern Cyprus, and vice versa. Both these recent developments, and the environmental transformation process of the Turkish Cypriot community by an island-wide recycling project, which was initiated as a zero budget project and currently supported by European Commission [77] clearly point to the fact that both technological and social enterprises are emerging in Northern Cyprus from the entrepreneurial spirit of the young generation.

Regarding the link between these structurally similar regions, the authors highlight recent findings by [78] pointing out to necessity entrepreneurship that can be a common feature in these regions. As put forward by [74], "the perception that the economy is weak and that there are no jobs available could be a decisive "push factor'" (p.1165) for the youth of these regions. What is needed is the design of effective self-employment policies, especially under consideration of regional actors such as universities [78].

\section{Conclusion and Limitations}

According to this study, the following findings can be highlighted to focus on the role of universities helping their students to become entrepreneurs. The primary research findings indicated that having an internship experience increases the odds of entrepreneurial action, which is identified as a channel shaping the perception of the students. In addition, if the students have someone in their 
families with an entrepreneurial background, they will be more likely to opt for an entrepreneurial experience themselves. Furthermore, contradicting the traditional examples of dropout entrepreneurs, the research findings indicated that students who undertake education to become an entrepreneur are more likely to become entrepreneurs. These findings create opportunities for universities and knowledge centers to focus on becoming entrepreneurial universities, which will also boost the economy, especially the small and poor cities in East Germany and Northern Cyprus. Structural similarities approach [3,4] and its application for competitiveness and innovation in economies [20] can be meaningful in the context of entrepreneurial support in innovation driven economies such as Germany, where potential entrepreneurs face difficulties regarding the accessibility of science parks, business incubators and subcontractors, and in efficiency driven economies such as Northern Cyprus, where entrepreneurship is a desired career choice and the plethora of opportunities to create start-ups needs to be matched by similar business incubation centers that are not yet present in Northern Cyprus. Hence, in both cases entrepreneurial universities can be accelerators of the transformation process of tacit knowledge to explicit knowledge that is relevant for the market. Targeting the considerations in becoming entrepreneurial universities shall be focusing on the perceptions of students (the nano dimension in the sense of [24]) and how these perceptions can turn into entrepreneurial opportunities for students and for the region, where business conceptions can be developed by introducing students to relevant capabilities associated with entrepreneurship.

Of course, the authors need to mention that self-reported entrepreneurial intentions do not reflect the whole picture. Not only is there a limitation associated with the unverifiable truth reporting in questionnaires, but also the probability of becoming real entrepreneurs cannot be directly deduced from the reported intentions. In spite of the fact that the participation rates at the surveys were high, the size is still limited. Therefore, the authors aim to emphasize that these are the results of pilot studies, since entrepreneurial intentions deserve a wider survey with a large number of students. In respect to the results, it can be seen that there is a group of students who chose their current course of studies with the target of being an entrepreneur-a contradictory result to the mainstream entrepreneur image, as described with known worldwide examples. However, this can also indicate a form of self-selection, highlighting the possibility that those who do not believe in this statement do not participate at the lectures but develop their own ideas elsewhere, even though they too are students. The authors cannot eliminate this possibility, yet due to privacy issues they can only reach students who show up at the lectures. Further research can concentrate on how to handle these potential entrepreneurs who pursue their degrees with the clear target of becoming an entrepreneur, since the recent findings of [66] also highlight that regardless of whether a student becomes a graduate or a dropout, the key issue is the decision to become an entrepreneur during the studies and not-contrary to the belief-a result of becoming a dropout. Since those dropouts cannot really escape from the disadvantages of being a dropout on the labor market [66], the transformation towards entrepreneurial universities can be useful for reducing the number of dropouts by providing competencies associated with becoming an entrepreneur to entrepreneurially inclined students. Clearly, universities focused too much on the teaching about entrepreneurship rather than introducing to students the necessary skills of entrepreneurship [65].

Learning objectives for entrepreneurial competencies were formulated by [79] for German universities as a result of semi-structured telephone interviews with university professors. The outcome is based on the fact that entrepreneurial competencies can be taught in a university environment, where the categories of these competencies are entrepreneurial knowledge, entrepreneurial social/technical skills, and motivational/volitional tendencies [79]. This new framework can be implemented in a broader context of knowledgization [19] enabling both social and technological entrepreneurship and the competencies associated with these, although the boundaries between the two are starting to dissolve [76]. An interesting natural experience would be to examine how the entrepreneurial intentions of students change over time due to their interactions with this entrepreneurship-supporting environment-since the emergence of entrepreneurial intentions may take time. In the case of social 
lead user entrepreneurship [49], more work needs to be done, since this concept can be of particular interest to target social problems in structurally similar regions of small and poor cities [2-4,20]. Due to the dispersed, locally available character of knowledge, any central planned attempt to solve the socioeconomic problems of these regions is doomed to fail-therefore, solving these problems can go through promoting social lead user entrepreneurship $[24,26,62]$. Whether the perceived social problems can be matched with solutions offered by social lead users, is an open topic and dependent on whether the transformation toward an entrepreneurial university can associate the newly developed and empirically observed aspect of social lead users. Also in this challenging phase, structural similarities in competitiveness and innovativeness as well as the choice of location of university graduates can be a helpful tool for shaping the trajectory of entrepreneurial development in the university context, since this development process is more of an evolutionary process than a revolutionary one $[3-5,20,23]$.

Author Contributions: Conceptualization, T.K., N.T. and B.E.; methodology, B.E.; formal analysis, T.K. and B.E.; investigation, N.T.; data curation, N.T., B.E. and T.K.; Writing-Original Draft preparation, T.K. and B.E.; Writing-Review and Editing, B.E. and T.K.; supervision, B.E.; project administration, T.K.

Funding: The authors acknowledge support by the Open Access Publications Funds of the SLUB / TU Dresden.

Acknowledgments: The authors would like to thank three anonymous referees, Georg Hirte, Marco Lehmann-Waffenschmidt, Jamil Salmi, the participants of the 24th Public Economics Meeting of the Spanish Public Economics Society at the University of Castilla-La Mancha, the Brown Bag Seminar of the Faculty of Business and Economics at TU Dresden and the 2nd International Higher Education Conference participants for the useful feedback.

Conflicts of Interest: The authors have no conflict of interest.

\section{References}

1. Amway. Amway Global Entrepreneurship Report 2018; Amway: Ada, MI, USA, 2018.

2. Maseland, R. Does Germany have an East-West Problem? Regional Growth Patterns in Germany since Reunification. Reg. Stud. 2014, 48, 1161-1175. [CrossRef]

3. Lehmann-Waffenschmidt, M.; Schwerin, J. Strukturähnlichkeiten ökonomischer Prozesse im Zeitablauf. In Die Entstehung des Modernen Europa 1600-1900; Mörke, O., North, M., Eds.; Böhlau: Vienna, Austria, 1998; pp. 121-148.

4. Lehmann-Waffenschmidt, M. Strukturähnlichkeiten und -ungleichheiten evolvierender Ökonomien. Wiss. Z. Tech. Univ. Dresd. 2008, 57, 105-109.

5. Buenstorf, G.; Geissler, M.; Krabel, S. Standortentscheidungen deutscher Hochschulabsolventen beim Berufseinstieg_Liegt (regionale) Schönheit im Auge des Betrachters? Jahrb. Reg. 2016, 36, 29-49. [CrossRef]

6. Mullen, F.; Apostolides, A.; Besim, M. The Cyprus Peace Dividend Revisited: A Productivity and Sectoral Approach; PRIO Research Centre: Nicosia, Cyprus, 2014; ISBN 978-82-7288-544-0.

7. Davidsson, P. Data replication and extension: A commentary. J. Bus. Ventur. Insights 2015, 3, 12-15. [CrossRef]

8. Kirzner, I.M. Entrepreneurial Discovery and the Competitive Market Process: An Austrian Approach. J. Econ. Lit. 1997, 35, 60-85.

9. Kuratko, D.F. Entrepreneurship theory, process, and practice in the 21st century. Int. J. Entrep. Small Bus. 2011, 13, 8. [CrossRef]

10. Mellor, R.B.; Coulton, G.; Chick, A.; Bifulco, A.; Mellor, N.; Fisher, A. Entrepreneurship for Everyone; SAGE: Thousand Oaks, CA, USA, 2009.

11. EUROSTAT. Statistics on Small and Medium-Sized Enterprises. Available online: http://ec.europa.eu/ eurostat/statistics-explained/index.php/Statistics_on_small_and_medium-sized_enterprises (accessed on 7 February 2019).

12. IfM. Informationen zum Mittelstand aus erster Hand; IfM: Bonn, Germany, 2018.

13. Girisim Egitim ve Danismanlik Merkezi. KKTC EKONOMİSİ BİLGI NOTU; Girisim Merkezi: Ankara, Turkey, 2016.

14. Thurik, A.R.; Carree, M.A.; van Stel, A.; Audretsch, D.B. Does Self-Employment reduce Unemployment? J. Bus. Ventur. 2008, 23, 673-683. [CrossRef] 
15. Becker, S.O.; Egger, P.H.; von Ehrlich, M. Going NUTS: The effect of EU Structural Funds on regional performance. J. Public Econ. 2010, 94, 578-590. [CrossRef]

16. Becker, S.O.; Egger, P.H.; von Ehrlich, M. Too much of a good thing? On the growth effects of the EU's regional policy. Eur. Econ. Rev. 2012, 56, 648-669. [CrossRef]

17. Becker, S.O.; Egger, P.H.; von Ehrlich, M. Absorptive Capacity and the Growth and Investment Effects of Regional Transfers: A Regression Discontinuity Design with Heterogeneous Treatment Effects. Am. Econ. J. Econ. Policy 2013, 5, 29-77. [CrossRef]

18. Erkut, B. Entrepreneurship and Economic Freedom: Do Objective and Subjective Data Reflect the Same Tendencies? Entrep. Bus. Econ. Rev. 2016, 4, 11-26. [CrossRef]

19. Kaya, T.; Sağsan, M. The Concept of "Knowledgization" for Creating Strategic Vision in Higher Education: A Case Study of Northern Cyprus. Educ. Sci. 2016, 41, 291-309. [CrossRef]

20. Erkut, B. Structural similarities of economies for innovation and competitiveness-A decision tree based approach. Stud. Oecon. Posnan. 2016, 4, 85-104. [CrossRef]

21. Krueger, N.F., Jr.; Reilly, M.D.; Carsrud, A.L. Competing Models of Entrepreneurial Intentions. J. Bus. Ventur. 2000, 15, 411-432. [CrossRef]

22. Dopfer, K. Evolutionary Economics: A Theoretical Framework. In The Evolutionary Foundations of Economics; Dopfer, K., Ed.; Cambridge University Press: Cambridge, UK, 2005.

23. Buenstorf, G. Creation and pursuit of entrepreneurial opportunities: An evolutionary economics perspective. Small Bus. Econ. 2007, 28, 323-337. [CrossRef]

24. Erkut, B. Product Innovation and Market Shaping: Bridging the Gap with Cognitive Evolutionary Economics. Indraprastha J. Manag. 2016, 4, 3-24.

25. Buenstorf, G. Process of Knowledge Sharing: From Cognitive Psychology to Economics. In The Economics of Knowledge Sharing; Helmstädter, E., Ed.; Edward Elgar: Cheltenham, UK, 2003.

26. Fuster, J.M. Hayek in today's cognitive neuroscience. Adv. Austrian Econ. 2011, 15, 3-11.

27. Etzkowitz, H.; Dzisah, J. Professors of Practice and the Entrepreneurial University. Int. High. Educ. 2008, 49, 10-11. [CrossRef]

28. Bliemel, M.J. Getting Entrepreneurship Education Out of the Classroom and into Students' Heads. Entrep. Res. J. 2013, 4, 237-260. [CrossRef]

29. Żur, A. Social Problems as Sources of Opportunity: Antecedents of Social Entrepreneurship Opportunities. Entrep. Bus. Econ. Rev. 2015, 3, 7-9. [CrossRef]

30. Balcioglu, H.; Atan, T.; Aga, M. Rekabet Edebilirlik Raporu; Turkish Cypriot Chamber of Commerce: Nicosia, Cyprus, 2016.

31. Rizzello, S.; Spada, A. The Oversight of Behavioral Economics on Hayek's Insights. In Hayek and Behavioral Economics; Palgrave Macmillan: London, UK, 2013; pp. 301-312.

32. Witt, U. Imagination and leadership-The neglected dimension of an evolutionary theory of the firm. J. Econ. Behav. Organ. 1998, 35, 161-177. [CrossRef]

33. Witt, U. Firms as realizations of entrepreneurial visions. J. Manag. Stud. 2007, 44, 1125-1140. [CrossRef]

34. Lehmann-Waffenschmidt, M. Gibt es eine Evolution in der Wirtschaft? In Neue Konzepte der Ökonomik-Unternehmen Zwischen Nachhaltigkeit, Kultur und Ethik; Antoni-Komar, I., Lautermann, C., Müller, J., Paech, N., Schattke, H., Schneidewind, U., Schulz, R., Eds.; Metropolis: Marburg, Germany, 2009.

35. Lehmann-Waffenschmidt, M. Predictability of Economic Processes and the Morgenstern Paradox. Swiss J. Econ. Stat. 1990, 126, 147-161.

36. Amway. Amway Global Entrepreneurship Report 2016; Amway: Ada, MI, USA, 2016.

37. Nicolaou, N.; Shane, S.; Cherkas, L.; Hunkin, J.; Spector, T.D. Is the Tendency to Engage in Entrepreneurship Genetic? Manag. Sci. 2008, 54, 167-179. [CrossRef]

38. Artinger, S.; Schade, C. Girls Will Be Girls: An Experimental Study on Female Entrepreneurship; HU Berlin: Berlin, Germany, 2013.

39. Feldman, H.D.; Koberg, C.S.; Dean, T.J. Minority small business owners and their paths to ownership. J. Small Bus. Manag. 1991, 29, 12-27.

40. Pruett, M.; Shinnar, R.; Toney, B.; Llopis, F.; Fox, J. Explaining Entrepreneurial Intentions of University Students: A Cross-Cultural Study. Int. J. Entrep. Behav. Res. 2009, 15, 571-594. [CrossRef]

41. Segal, G.; Schooenfeld, J.; Borgia, D. Which Classroom-Related Activities Enhance Students' Entrepreneurial Interests and Goals? A Social Cognitive Career Theory Perspective. Acad. Entrep. J. 2015, 13, 79-98. 
42. Frazier, B.J.; Niehm, L.S. Predicting the Entrepreneurial Intentions of Non-Business Majors: A Preliminary Investigation. In Proceedings of the USASBE/SBI Conference, Tucson, Arizona, 12-15 January 2006.

43. Hytti, U. New Meanings for Entrepreneurs: From Risk-Taking Heroes to Safe-Seeking Professionals. J. Organ. Chang. Manag. 2005, 18, 594-611. [CrossRef]

44. Gibney, B.; Howery, K. Just How Risky Is Entrepreneurship, Really? Harv. Bus. Rev. 2012, 1, 4-7.

45. Pittaway, L.A.; Gazzard, J.; Shore, A.; Williamson, T. Student clubs: Experiences in entrepreneurial learning. Entrep. Reg. Dev. 2015, 27, 127-153. [CrossRef]

46. Fritsch, M. Entrepreneurship: Theorie, Empirie, Politik; Springer: Berlin/Heidelberg, Germany, 2016.

47. Fritsch, M.; Wyrwich, M. The Long Persistence of Regional Levels of Entrepreneurship: Germany 1925 to 2005. Reg. Stud. 2014, 48, 955-973. [CrossRef]

48. Von Hippel, E. Lead Users: A Source of Novel Product Concepts. Manag. Sci. 1986, 32, 791-806. [CrossRef]

49. Thierbach, N. Intentionen Bezüglich der Gründung eines Sozialen Unternehmens: Die Konzeptionalisierung des Sozialen Lead-User Entrepreneurs; AV: Riga, Latvia, 2017.

50. Herstatt, C.; von Hippel, E. From Experience: Developing New Product Concepts via the Lead User Method: A Case Study in a "Low-Tech" Field. J. Prod. Innov. Manag. 1992, 9, 213-221. [CrossRef]

51. Zupan, B.; Stevina Nabergoj, A. Developing Design Thinking Skills in Entrepreneurship Education. In Proceedings of the 2012 International Design Management Research Conference, Boston, MA, USA, 8-9 August 2012; pp. 525-535.

52. Lange, J.E.; Marram, E.; Jawahar, A.S.; Yong, W.; Bygrave, W. Does an entrepreneurship education have lasting value? A study of careers of 4000 alumni. Front. Entrep. Res. 2011, 31, 210-224.

53. Kolvereid, L.; Isaksen, E. New Business Start-Up and Subsequent Entry into Self-Employment. J. Bus. Ventur. 2006, 21, 866-885. [CrossRef]

54. Rasmussen, E.A.; Sørheim, R. Action-based entrepreneurship education. Technovation 2006, 26, $185-194$. [CrossRef]

55. Mankart, J.; Rodano, G. Personal bankruptcy law, debt portfolios, and entrepreneurship. J. Monet. Econ. 2015, 76, 157-172. [CrossRef]

56. Lehmann-Waffenschmidt, M. Contingency and causality in economic processes-Conceptualizations, formalizations, and applications in counterfactual analysis. Eur. Rev. 2010, 18, 481-505. [CrossRef]

57. NEU. Faculty of Economics and Administrative Sciences. Available online: https://neu.edu.tr/academic/ faculties / faculty-of-economics-and-administrative-sciences/?lang=en (accessed on 21 February 2019).

58. TU Dresden. Statistischer Jahresbericht 2015; TU Dresden: Dresden, Germany, 2016.

59. Sekaran, U. Research Methods for Business: A Skill-Building Approach; Wiley: New York, NY, USA, 1992.

60. Gurel, E.; Altinay, L.; Daniele, R. Tourism students' entrepreneurial intentions. Ann. Tour. Res. 2010, 37, 646-669. [CrossRef]

61. Kaiser, H.F. An index of factorial simplicity. Psychometrika 1974, 39, 31-36. [CrossRef]

62. Hayek, F.A. von The Pretence of Knowledge. Am. Econ. Rev. 1989, 79, 3-7.

63. Bredvold, R.; Skålén, P. Lifestyle Entrepreneurs and their Identity Construction: A Study of the Tourism Industry. Tour. Manag. 2016, 56, 96-105. [CrossRef]

64. Mellor, R.B. Achieving Enterprise: Teaching Entrepreneurship and Innovation in Business and Academia; FGF Entrep.; Eul Verlag: Cologne, Germany, 2005.

65. Williams Middleton, K.; Donnellon, A. Personalizing Entrepreneurial Learning: A Pedagogy for Facilitating the Know Why. Entrep. Res. J. 2014, 4, 167-204. [CrossRef]

66. Buenstorf, G.; Nielsen, K.; Timmermans, B. Steve Jobs or No Jobs? Entrepreneurial activity and performance among Danish college dropouts and graduates. Small Bus. Econ. 2017, 48, 179-197. [CrossRef]

67. Forum, W.E. Shaping Davos: Creating 75 Million Entrepreneurs: Is This Possible? Available online: https: / / www.weforum.org/events / world-economic-forum-annual-meeting-2016/sessions / creating-75million-entrepreneurs-is-this-possible/ (accessed on 7 February 2019).

68. Habisch, A.; Wegner, M. Germany overcoming the heritage of corporatism. In Corporate Social Responsibility Across Europe; Habisch, A., Jonker, J., Wegner, M., Schimdpeter, R., Eds.; Springer: Berlin/Heidelberg, Germany, 2005; pp. 111-123, ISBN 3540232516.

69. Von Kieter, A.-C. Die Ministerin, die Wissen schafft. UNICUM 2016, March, 20-22.

70. EUROSTAT. Unemployment Statistics. 2018. Available online: https://ec.europa.eu/eurostat/statisticsexplained/index.php/Unemployment_statistics\#Main_statistical_findings (accessed on 7 February 2019). 
71. STATISTA. Jugendarbeitslosenquote (15 bis unter 25 Jahre) in Deutschland nach Bundesländern im Januar 2019. Available online: https://de.statista.com/statistik/daten/studie/189105/umfrage/ jugendarbeitslosenquote-nach-bundeslaendern/ (accessed on 7 February 2019).

72. Ragnitz, J. Prospects for Regional Development and Entrepreneurship in East Germany; ifo Dresden: Dresden, Germany, 2009.

73. Kay, R.; Suprinovic, O. Unternehmensnachfolgen in Deutschland 2014 bis 2018; Daten und Fakten, Institut für Mittelstandsforschung (IfM): Bonn, Germany, 2013.

74. Dvouletý, O.; Mühlböck, M.; Warmuth, J.; Kittel, B. 'Scarred' young entrepreneurs. Exploring young adults' transition from former unemployment to self-employment. J. Youth Stud. 2018, 21, 1159-1181. [CrossRef]

75. Minola, T.; Criaco, G.; Cassia, L. Are youth really different? New beliefs for old practices in entrepreneurship. Int. J. Entrep. Innov. Manag. 2014, 18, 233-259. [CrossRef]

76. Tuomi, I. Networks of Innovation; Oxford University Press: Oxford, UK, 2006; ISBN 9780199269051.

77. Erkut, B.; Kaya, T.; Thierbach, N. Social Lead Users: A Perspective of Cognitive Evolutionary Economics; TU Dresden: Dresden, Germany, 2019.

78. Dvouletý, O.; Lukes, M. Review of Empirical Studies on Self-Employment out of Unemployment: Do Self-Employment Policies Make a Positive Impact? Int. Rev. Entrep. 2016, 14, 361-376.

79. Weinberger, E.; Schefczyk, M. HEED—Higher Entrepreneurship Education Diagnostic; Technische Universität Dresden: Dresden, Germany, 2015.

(C) 2019 by the authors. Licensee MDPI, Basel, Switzerland. This article is an open access article distributed under the terms and conditions of the Creative Commons Attribution (CC BY) license (http://creativecommons.org/licenses/by/4.0/). 